\title{
PENGARUH SISTEM OLAH TANAH DAN APLIKASI MULSA BAGAS TERHADAP ASAM HUMAT DAN FULVAT PERTANAMAN TEBU (Saccharum officinarum L.) RATOON KE 3 DI PT GUNUNG MADU PLANTATIONS
}

\author{
Raden Saleh Ganda Bhakti, Sarno, Nur Afni Afrianti \& Muhajir Utomo \\ Jurusan Agroteknologi, Fakultas Pertanian,UniversitasLampung, \\ J1. Prof. Soemantri Brodjonegoro, No. 1 Bandar Lampung 35145 Indonesia \\ Email: radensalehganda@gmail.com
}

\begin{abstract}
ABSTRAK
Pertanaman tebu di PT.GMP pada pengelolaan lahan yang lebih dari 25 tahun menyebabkan terjadinya degradasi lahan tersebut, ditandai dengan penurunan kualitas tanah yang terjadi diantaranya adalah cepat habisnya atau rendahnya kadar bahan organik di dalam tanah akibat pengolahan tanah intensif tersebut.Sistem tanpa olah tanah yang ditambah dengan penggunakan mulsa berbasis limbah tebu (bagas) diharapkan mampu meningkatkan kadar bahan organik tanah (BOT), yang juga akan meningkatkan kadar asam humat dan asam fulvat dalam tanah. Asam humat dan asam fulvat merupakan salah satu substansi bahan organik dari bahan humus yang penting dalam menentukan kesuburan tanah. Penelitian ini bertujuan untuk mengetahui pengaruh sistem olah tanah dan pemberian mulsa bagas pada lahan pertanaman tebu PT. GMP terhadap konsentrasi asam humat dan asam fulvat tanah Ultisol ratoon ke-3. Penelitian ini dirancang secara split plot dalam rancangan acak kelompok (RAK) dengan 5 kali ulangan. Petak utama yaitu sistem olah tanah yang terdiri dari tanpa olah tanah (T0) dan olah tanah intensif (T1). Anak petak adalah aplikasi mulsa bagas yang terdiri dari tanpa mulsa bagas (M0) dan mulsa bagas 80 $\mathrm{t} \mathrm{ha}^{-1}$ (M1). Adapun kombinasi perlakuan yang diterapkan adalah sebagai berikut: T0M0 = tanpa olah tanah + tanpa mulsa bagas, T0M1 = tanpa olah tanah + mulsa bagas $80 \mathrm{tha}^{-1}$, T1M0 $=$ olah tanah intensif + tanpa mulsa bagas, dan T1M1 = olah tanah intensif + mulsa bagas $80 \mathrm{tha}^{-1}$. Data yang diperoleh diuji homogenitasnya dengan Uji Bartlet dan aditivitasnya dengan Uji Tukey, serta uji lanjut dengan Uji Beda Nyata Terkecil (BNT). Hasil penelitian menunjukkan bahwa perlakuan sistem olah tanah dan pemberian mulsa bagas tidak berpengaruh nyata terhadap kadar asam humat dan asam fulvat pada pertanaman tebu ratoon ke-3.
\end{abstract}

Kata Kunci: asam fulvat, asam humat, mulsa bagas, olah tanah intensif, dan tanpa olah tanah.

\section{PENDAHULUAN}

Tanaman tebu (Sacchrum officinarum L.) termasuk salah satu anggota dari familia Gramineae, subfamilia Andropogonae. Tebu merupakan tanaman perkebunan yang berperan penting sebagai bahan baku produksi gula. Pemerintah Indonesia berupaya meningkatkan penanaman bahan pangan pokok diantaranya penanaman tebu untuk mengatasi rendahnya produksi gula di Indonesia.PT GMP sudah lebih dari 25 tahun menerapkan sistem olah tanah intensif (OTI).OTI dalam jangka panjang dapat memberikan dampak berkurangnya kesehatan dan kesuburan tanah sehingga dapat menurunkan produksi tanaman tebu.Salah satu upaya untuk menjaga kelestarian mikroorganisme di dalam tanah diperlukan penanganan olah tanah konservasi (OTK) yang berwawasan ramah lingkungan.Sistem OTK mampu memperbaiki kesuburan tanah lebih baik dari pada sistem OTI umumnya pada tanah ultisol. OTK terdiri dari dua sistem olah tanah yaitu olah tanah minimum (OTM) gulma dibabat dengan menggunakan alat mekanis kemudian dikembalikan ke lahan pertanaman dan tanpa olah tanah (TOT) dengan mengendalikan gulma menggunakan herbisida, gulma dibiarkan mati dan digunakan sebagai mulsa (Utomo, 2006).

Menurut data PT GMP (2010)produksi gula PT. Gunung Madu Plantation mengalami penurunan. Pada tahun 2002 produksi gula di perusahaan tersebut sebesar 28.213 tonGula Kristal Putih (GKP), lalu tahun 2005 sebesar 6.619 ton, tahun 2009 sebesar 8.004 ton dan tahun 2010 sebesar 8.369 ton. Menurut catatan data Badan Litbang Pertanian, produksi gula nasional tahun 2011 mencapai 2.228.591 ton Gula Kristal Putih (GKP) dan meningkat menjadi 2.580 .000 ton pada tahun 2012 dan pada tahun 2014 mencapai 2.956.000 ton GKP.Untuk memenuhi kebutuhan gula di Indonesia maka harus dilakukan usaha yang lebih optimal dalam meningkatkan 
produktivitas gula nasional dengan memperhatikan faktor-faktor penting dalam peningkatan produksi gula dalam negeri untuk mengurangi impor gula nasional.

Seiring dengan meningkatnya kebutuhan tebu di Indonesia beberapa upaya yang dapat dilakukan untuk meningkatkan produksi gula antara lain dengan pengelolaan tanah yang tepat, melalui sistem tanpa olah tanah (TOT) dan pemberian mulsa organik. TOT yang bertujuan untuk menyiapkan lahan agar tanaman dapat tumbuh dan berproduksi secara optimum, dengan tetap memperhatikan konservasi tanah dan air. Teknologi tanpa olah tanah (TOT) merupakan rumpun teknologi olah tanah konservasi (OTK) paling ekstrim. Seperti pada sistem OTK, disamping kelayakan fisik seperti persyaratan mulsa dipermukaan lahan lebih dari $30 \%$ dan juga kelayakan sosisal ekonomi juga harus dipertimbangkan (Utomo, 1990).

Penggunaan mulsa yang dapat memperbaiki kualitas tanah yaitu selain sumber bahan organik, dapat menghemat dalam penggunaan air dengan mengurangi laju evaporasi dari permukaan lahan, memperkecil fluktuasi suhu tanah sehingga menguntungkan pertumbuhan akar dan mikroorganisme tanah, serta memperkecil laju erosi tanah baik akibat tumbukan butirbutir hujan maupun aliran permukaan dan menghambat laju pertumbuhan gulma. Pada lahan yang diolah secara intensif akan menyebabkan tanah mengalami pemadatan dan rawan terhadap erosi. Pengolahan tanah juga dapat merusak agregasi tanah dan meningkatkan degradasi bahan organik yang akan menyebabkan tingkat kesuburan tanah menurun (Rovira dan Greacen, 1957).

Pemanfaatan lahan secara intensif mulanya berdampak positif dalam meningkatkan produksi pertanian. Namun didaerah tropis seperti Indonesia, pengelolaan tanah secara berlebihan dan terus menerus justru akan memacu erosi tanah dan emisi gas $\mathrm{CO}_{2}$ secara signifikan. Dampak negatif yang dapat ditimbulkan antara lain pemampatan atau pemadatan pada tanah, berkurangnya ketersediaan air tanah, semakin kurang berkembangnya sistem perakaran tanaman, penurunan kandungan bahan organik, kerusakan struktur dan agregat tanah (Soepardi, 1993).

Bahan organik merupakan bahan penting dalam menciptakan kesuburan tanah baik secara fisik, kimia, maupun biologi tanah dan bersumber dari serasah tanaman berupa akar, batang, ranting dan daun yang akan mengalami dekomposisi sehingga menghasilkan senyawa kompleks yang resisten pelapukan, berwarna coklat, bersifat koloid dan dikenal sebagai humus (Hakim dkk, 1986).Secara umum asam humat diyakini berasal dari dekomposisi lignin atau karbohidrat tanaman yang membusuk. Asam humat biasanya kaya akan karbon, yang berkisar antara $41-47 \%$, namun bahan ini juga dapat mengandung nitrogen dan bahan organik (Tan 1995; Robinson 1995). Asam humat mempunyai peranan yang penting dalam menyokong kehidupan mikroorganisme didalam tanah. Asam organik ini dapat meningkatkan permeabilitas membran dan membantu memperlancar nutrisi untuk menembus dinding sel, meningkatkan produksi klorofil dan fotosintesis, menstimulasi hormon dan meningkatkan aktivitas enzim (Bio Flora, 1997).Asam fulvat dari bahan organik yang ditambahkan pada tanah mampu memperbaiki ketersediaan fosfat dengan menurunkan jerapan fosfat. Asam fulvat ternyata berperan sangat nyata baik pada pelepasan P-terjerap maupun ketersediaan P yang lebih besar dibanding asam humat ( $\mathrm{He} \mathrm{dkk}, 1992)$.

\section{BAHAN DAN METODE}

Waktu dan Tempat Penelitian. Penelitian dilakukan pada lahan pertanaman tebu di PT. Gunung Madu Plantations (GMP), Lampung Tengah pada bulan Januari - September 2014.Percobaan dilakukan dengan dua sistem olah tanah, yaitu sistem olah tanah intensif dan sistem tanpa olah tanah serta aplikasi mulsa bagas jangka panjang dari tahun 2010 - 2020. Waktu penelitian 3 Bulan Setelah Perlakuan (BSP) pada ratoon ke-3. Analisis tanah dilakukan di Laboratorium Ilmu Tanah, Fakultas Pertanian, Universitas Lampung.

Alat dan Bahan. Bahan yang digunakan dalam penelitian ini adalah sampel tanah yang diambil dari lokasi penelitian pada kedalaman $0-20 \mathrm{~cm}$. Bahan kimia untuk menganalisis asam humat dan fulvat diantaranya $\mathrm{NaOH}$, $\mathrm{H}_{2} \mathrm{SO}_{4}$ gas $\mathrm{N}_{2}, \mathrm{HCl}, \mathrm{K}_{2} \mathrm{Cr}_{2} \mathrm{O}_{7}$, Diphenilamin dan $\mathrm{HCl}$. Alat-alat yang digunakan adalah kantong plastik, sekop, ayakan $2 \mathrm{~mm}$, botol plastik, spektrofotometer, setrifius, alat pengaduk, $\mathrm{pH}$ meter, dan alat-alat gelas untuk analisis tanah.

Metode Penelitian. Penelitian ini disusun secara split plot dalam rancangan acak kelompok terdiri dari 4 perlakuan dengan 5 ulangan atau 20 satuan percobaan. Petak utama yaitu sistem olah tanah. Yang terdiri dari tanpa olah tanah (T0) dan olah tanah intensif(T1) serta anak petak adalah aplikasi mulsa bagas yang terdiri dari tanpa mulsa bagas (M0) dan mulsa bagas 80 tha $^{-1}(\mathrm{M} 1)$. Dengan demikian terbentuk 4 kombinasi perlakuan, yaitu: T0M0 = tanpa olah tanah + tanpa mulsa bagas (BBA), T0M1 = tanpa olah tanah + mulsa bagas (BBA) $80 \mathrm{t}$ $\mathrm{ha}^{-1}, \mathrm{~T} 1 \mathrm{M} 0=$ olah tanah intensif + tanpa mulsa bagas (BBA), T1M1 = olah tanah intensif + mulsa bagas (BBA) $80 \mathrm{t} \mathrm{ha}^{-1}$. Semua perlakuan diaplikasikan pupuk dasar yaitu pupuk Urea dengan dosis $300 \mathrm{~kg} \mathrm{ha-1}$, TSP 200 $\mathrm{kg} \mathrm{ha}^{-1}, \mathrm{KCl} 300 \mathrm{~kg} \mathrm{ha}^{-1}$, dan aplikasi bagas, blotong, 
dan abu (BBA) segar dengan perbandingan (5:3:1) $80 \mathrm{t}$ $\mathrm{ha}^{-1}$. Data yang diperoleh dianalisis dengan sidik ragam pada taraf $5 \%$ dan $1 \%$, yang sebelumnya telah diuji homogenitas ragamnya dengan Uji Bartlett dan aditivitasnya dengan Uji Tukey. Rata-rata nilai tengah diuji dengan uji BNT pada taraf 5\% dan 1\%. Uji korelasi dilakukan antara asam humat dan fulvat dengan $\mathrm{C}$ organik tanah dan $\mathrm{pH}$ tanah untuk mengetahui tingkat korelasi antara variabel utama dan variabel pendukung.

\section{HASIL DAN PEMBAHASAN}

Hasil analisis ragam menunjukkan bahwa perlakuan sistem olah tanah dan aplikasi mulsa bagas dan interaksinya tidak berpengaruh nyataterhadap konsentrasi asam humat tanahdan asam fulvat pada pengamatan 3 Bulan Setelah Perlakuan (BSP) ratoon ke-3 pertanaman tebu dapat dilihat pada Tabel 1. Berdasarkan uji korelasi menunjukkan bahwa C-Organik tanah dan $\mathrm{pH}$ tanah tidak ada korelasi yang nyata pada saat tanaman tebu berumur 3 Bulan Setelah Perlakuan (BSP) dipertanaman tebu ratoon ke-3, artinya tinggi rendahnya $\mathrm{C}$-organik tanah dan $\mathrm{pH}$ tanah tidak mempengaruhi asam humat tanah dan asam fulvat.

Bahan organik tanah adalah materi yang berasal dari organisme tanaman atau hewan yang ada di dalam tanah dan kemudian mengalami proses dekomposisi. Dekomposisi bahan organik dalam tanah pada akhirnya akan meninggalkan materi yang tahan terhadap proses dekomposisi yang disebut dengan humus. Humus merupakan sumber muatan negatif tanah dan tempat pengikatan unsur-unsur hara dalam tanah (Bot dan Benites, 2005).Bahan organik dibedakan menjadi bahan terhumifikasi dan tak terhumifikasi. Bahan terhumifikasi dikenal sebagai humus atau senyawa humat, sedangkan bahan-bahan tak terhumifikasi atau komponen non humus adalah senyawa-senyawa karbohidrat, asam amino, protein, lipid, asam nukleat, dan lignin (tan, 1995 dan Goh, 1980). Fraksi humat digolongkan ke dalam (1) asam humat, yakni fraksi yang larut dalam basa, tidak larut dalam asam dan alkohol; (2) asam fulvat, merupakan fraksi yang larut dalam asam dan basa; dan (3) humin, yakni bagian yang tidak dapat larut (Goh, 1980).

Olah tanah intensifyang dilakukan PT GMP dalam penyiapan lahannyatelah berjalan selama lebih dari 25 tahun.Pada penelitian ini bahan organik yang digunakan adalah mulsa bagas yang disebar di atas permukaan tanah (Ultisol). Sedangkan pada lahan penelitian ini sistem tanpa olah tanah (TOT) telah berjalan 3 tahun 3 bulan tanah tidak diolah sama sekali, gulma yang tumbuh dikendalikan dengan cara manual kemudian sisagulma dikembalikan ke lahan sebagai mulsa. sedangkan pada petak olah tanahintensif (OTI), pada perlakuan mulsa dan tanpa mulsa tanah diolah sesuai dengansistem pengolahan tanah yang diterapkan di PT GMP yaitu sebanyak 3 kali pengolahan dengan menggunakan bajak dalam setahun. Pengendalian gulma dilakukan dengan cara mekanik dan sisa tanaman gulma dibuang dari petak percobaan.

Dari hasil pengamatan tabel 1 menunjukan bahwa perlakuan pengolahan tanah dan aplikasi mulsa bagas tidak memberikan pengaruh nyata terhadap konsentrasi asam humat dan asam fulvat 3 BSP (Bulan Setelah Perlakuan) ratoon ke-3. Hal ini diduga waktu 3 BSP (Bulan Setelah Perlakuan) pada ratoon ke-3 belum

Tabel 1. Pengaruh sistem olah tanah dan aplikasi mulsa bagas terhadap konsentrasi asam humat tanah dan asam fulvat pada pengamatan 3 BSP, ratoon ke-3 pertanaman tebu

\begin{tabular}{lcc}
\hline & Asam humat & Asam fulvat \\
\cline { 2 - 3 } Perlakuan & $(\%)$ C-Organik & $(\%)$ C-Organik \\
\hline T0M0 & $22,89 \mathrm{a}$ & $60,66 \mathrm{a}$ \\
T0M1 & $21,28 \mathrm{a}$ & $59,54 \mathrm{a}$ \\
\hline BNT $_{0,05}$ & 6,02 & 4,41 \\
\hline T1M0 & $22,44 \mathrm{a}$ & $59,48 \mathrm{a}$ \\
T1M1 & $21,55 \mathrm{a}$ & $59,93 \mathrm{a}$ \\
\hline BNT $_{0,05}$ & 4,89 & 8,27 \\
\hline
\end{tabular}

Keterangan: $\mathrm{T}_{0}=$ Tanpa olah tanah; $\mathrm{T}_{1}=$ Olah tanah intensif; $\mathrm{M}_{0}=$ tanpa mulsa; $\mathrm{M}_{1}=$ Mulsa bagas 80 tha $^{-1}$; BSP = Bulan Setelah Perlakuan. Angka- angka yang diikuti huruf yang sama pada kolom yang sam tidak berpengaruh nyata berdasarkan uji BNT pada taraf $5 \%$. 
cukup untuk mendekomposisi bahan organik menjadi karbon.Hal ini didukung Makelew (2001) yang melaporkan bahwa setelah 16 tahun, penerapan sistem tanpa olah tanah (TOT) baru menunjukkan kemampuan mempertahankan kandungan bahan organik lebih baik dibandingkan dengan pengolahan tanah intensif. Hal ini juga didukung oleh hasil penelitian Widodo (2015) yang menyatakan perlakuan sistem olah tanah serta pemberian mulsa bagas pada pertanaman tebu tidak mempengaruhi karbon mikroorganisme tanah (C-mik) pada 9 BSP dan 12 BSP tahun ke-3. Hal ini tentunya akan mempengaruhi konsentrasi asam humat dan asam fulvat didalam tanah.

Dari hasil pengamatan pada Tabel 2 dan Tabel 3 menunjukkan bahwa perlakuan sistem olah tanah dan aplikasi mulsa bagas tidak berpengaruh nyata terhadap $\mathrm{C}$-organik tanah dan $\mathrm{pH}$ tanah. Hal ini didugatingginya kadar C/N rasio bagas (86) menjadi salah satu penyebab tidak berpengaruhnya mulsa terhadap asam humat dan asam fulvat dalam tanah(Harmoko, 2008).Hasil penelitian Agustina (2008) dan Ensminger (1990)menyatakan bahwa bagas sebenarnya tidak dapat langsung diaplikasikan ke lahan pertanaman tebu karena nisbah $\mathrm{C} / \mathrm{N}$ bagas yang tinggi.Apabila diaplikasikan langsung maka dekomposisi berjalan lambat dan akan terjadi imobilisasi unsur hara dalam tanah. Menurut Sarno (2004) proses perombakan bahan organik di dalam tanah sangat dipengaruhi kadar $\mathrm{C} / \mathrm{N}$ rasio dari bahan organik tersebut. Bahan organik yang berkualitas rendah (nisbah $\mathrm{C} / \mathrm{N}>25$ dan kandungan $\mathrm{N}<2 \%$ ) sehingga proses dekomposisi bahan tersebut organiknya menjadi berjalan lambat dan humus (asam humat dan asam fulvat) yang merupakan hasil akhir proses dekomposisi juga lambat terbentuk. Sebaliknya bahan organik yang berkualitas tinggi (nisbah $\mathrm{C} / \mathrm{N}<25$ dan kandungan $\mathrm{N}>2 \%$ ) proses dekomposisi berjalan cepat dan humus (asam humat dan asam fulvat) hasil akhir proses dekomposisi jugacepat terbentuk.

Kandungan asam humat dan asam fulvat sangat berkaitan erat dengan karbon dan nitrogen dari bahan organik tanah (Singaram, 2005).Laju dekomposisi bahan organik yang menghasilkan humus ( asam humat dan asam fulvat) sangat dipengaruhi oleh kandungan $\mathrm{N}$ yang ada dalam bahan organik tersebut. Semakin rendah kadar $\mathrm{N}$ dalam bahan organik tersebut maka laju dekomposisi berjalan lambat. Hal ini didukung oleh Sarno dkk, (1998) dan Tate, (1987) menyatakan bahwa adanya kandungan $\mathrm{N}$ dalam tanah akan meningkatkan tingkat humifikasi dalam tanah akibatnya kadar asam humat dan fulvat dalam tanah ikut meningkat, begitupun jika kandungan

Tabel 2. Pengaruh sistem olah tanah dan aplikasi mulsa bagas pada pertanaman tebu terhadap C-Organik dan $\mathrm{pH}$ tanah pada pengamatan 3 BSP, ratoon ke-3 pertanaman tebu

\begin{tabular}{ccc}
\hline \multirow{2}{*}{ Perlakuan } & $\begin{array}{c}\text { C-Organik } \\
(\%)\end{array}$ & $\begin{array}{c}\mathrm{pH} \text { tanah } \\
\left(\mathrm{H}_{2} 0\right)\end{array}$ \\
\cline { 2 - 3 } & $3 \mathrm{BSP}$ & $3 \mathrm{BSP}$ \\
\hline $\mathrm{T}_{0} \mathrm{M}_{0}$ & 1,40 & 6,04 \\
$\mathrm{~T}_{0} \mathrm{M}_{1}$ & 1,33 & 6,06 \\
$\mathrm{~T}_{1} \mathrm{M}_{0}$ & 1,36 & 6,24 \\
$\mathrm{~T}_{1} \mathrm{M}_{1}$ & 1,35 & 5,97 \\
\hline
\end{tabular}

Keterangan : $\mathrm{T}_{0}=$ Tanpa olah tanah; $\mathrm{T}_{1}=$ Olah tanah intensif; $\mathrm{M}_{0}=\operatorname{tanpa}$ mulsa; $\mathrm{M}_{1}=$ Mulsa bagas 80 tha $^{-1}$; BSP $=$ Bulan Setelah Perlakuan.

Tabel 3. Ringkasan uji korelasi C-organik tanah dan $\mathrm{pH}$ tanah dengan konsentrasi asam humat tanah dan asam fulvat pada pengamatan 3 BSP, ratoon ke-3 pertanaman tebu

\begin{tabular}{lcc}
\hline \multirow{2}{*}{ Pengamatan } & \multicolumn{2}{c}{ F Hitung } \\
\cline { 2 - 3 } & Asam humat & Asam fulvat \\
\hline C-Organik & $3,02^{\text {th }}$ & $2,78^{\text {tn }}$ \\
pH tanah & $0.09^{\text {th }}$ & $0,20^{\text {tn }}$ \\
\hline
\end{tabular}

Keterangan: $\mathrm{tn}=$ tidak nyata; $\mathrm{BSP}=$ bulan setelah perlakuan. 
$\mathrm{N}$ dalam tanah menurun maka tingkat humifikasi dalam tanah ikut menurun. Selain tingginya kadar $\mathrm{C} / \mathrm{N}$ rasio bagas, Hal ini juga diduga menjadi salah satu penyebab tidak berpengaruhnya mulsa bagas terhadap asam humat dan asam fulvat dalam tanah.

Serat bagas mengandung serat rata-rata $47,7 \%$ , 3,3 gula dan 48-52\% mengandung air. Sebagian besar terdiri dari selulosa 37,65\% dan lignin22,09\%.Jika bahan organik mempunyai kandungan lignin tinggi kecepatan mineralisasi Nakan lambat. Lignin adalah senyawa polimer pada jaringan tanaman berkayu yangmengisi rongga antar sel tanaman sehingga menyebabkan jaringan tanaman menjadikeras dan sulit untuk dirombak oleh organisme tanah. Pada jaringan berkayu, kandunganlignin bisa mencapai $38 \%$ (Stevenson, 1982). Hasil penelitian Hairiah dkk. (2000) menunjukkan bahwa penambahan bagas dan serasah daun tebu menyebabkan immobilisasi $\mathrm{N}$ pada lapisan tanah 0-5 cm, pada hampir seluruh waktu pengamatan hingga 7 bulan. Pada kedalaman $5-20 \mathrm{~cm}$ imobilisasi N hanya terjadi hingga waktu 5 bulan setelah pemberian. Oleh karena itu, sebelum diaplikasikan ke lahan sebaiknya dilakukan pengomposan atau dicampur dengan bahan organik yang memiliki nisbah $\mathrm{C} / \mathrm{N}$ rendah. Pengomposan sendiri merupakan penguraian bahan organik menjadi bahan yang mempunyai nisbah $\mathrm{C} / \mathrm{N}$ yang rendah. Dari hasil penelitian Sitepu (2006) Penambahan inokulum Isolat kotoran sapi dan Isolat kotoran gajah menghasilkan kinerja proses pengkomposan yang lebih baik disbanding control. Kompos yang dihasilkan selama 40 hari pengomposan dengan penambahan inokulum Isolat kotoran sapi mempunyai $\mathrm{C} / \mathrm{N}$ ratio 25 .

\section{KESIMPULAN}

Dari hasil penelitian dapat disimpulkan bahwa Sistem pengolahan tanah tidak berpengaruh nyata terhadap konsentrasi asam humat dan fulvat tanah pada dan 3 bulan setelah perlakuan (BSP) ratoon 3. Aplikasi mulsa bagas tidak berpengaruh nyata terhadap konsentrasi asam humat dan fulvat tanah pada 3 bulan setelah perlakuan (BSP) ratoon 3. Tidak terdapat interaksi antara sistem olah tanah dan aplikasi mulsa bagas pada 3 bulan setelah perlakuan (BSP) terhadap konsentrasi asam humat dan fulvat tanah ratoon ke 3 .

\section{DAFTAR PUSTAKA}

Agustina. 2008. Isolasi dan Uji Aktivitas Selulose Mikroba Termofilik dari Pengomposan
AmpasTebu (Bagasse). Skripsi. Universitas Lampung.

Badan Litbang Pertanian. (2011). Analisis Kebijakan Tentang Kebijakan Komprehensif Pergulaan Nasional. 319-346

Bio Flora. 1997. Bio Flora International Breakthrough in Adding Humic Acid to Soil Biomass. Bio Flora International. Good Year A.Z

Bot, A and J. Benites. 2005. The Importance of Soil Organic Matter. Publishing Management Services Italy Faber,B.1995. Organic Matter in Soil Aids Structure, Nutrient Exchange and Fertilty. Subtropical Fruit News 3 (1): 8-9

Ensminger, M. L., 1990. Feed and Nutrition. 2" Edition. The Ensminger Publishing. Company, California.

Goh, K.M. 1980. Dynamics and stability of organic matter. Dalam Soil with Variable Charge. Editor B.K.G. Theng. Soil Bareau, Depart. Of Sci and Ind. Res., Lower Hutt, pp. 373-393.

Hakim, N., M.Y. Nyakpa, A.M. Lubis, S.G. Nugroho, M.A. Diha, G.B.Hong, H.H. Bailey. 1986. DasardasarIlmu Tanah. Universitas Lampung. Bandarlampung. $488 \mathrm{hlm}$.

Hairiah, K., Widianto, Utami, S.R., Suprayogo, D., Sitompul, S.M., Sunaryo, Lusiana B.,Mulia, R., Van Noordwijk, M. dan Cadisch, G., 2000. Pengelolaan Tanah Secara Biologi: Pengaman pada tanah masam di daerah Tropika Basah. ISBN. 979-95537-7-6. ICRAF-Bogor. 187 p

Harmoko, J. 2008. Pengaruh Penambahan Jenis Sumber Nitrogen Terhadap Kinerja Proses Pengomposan Limbah Padat Tebu (Bagasse, Blotong, dan Abu). Skripsi. Universitas Lampung. Bandar Lampung.

He X.T., S.J. Traina and T.J. Logan. 1992. Chemical Properties of Municipal Solid waste Composts. J. Environ. Qual. 21: p. 318 - 329.

Makalew, A. D. N. 2001. Keanekaragaman Biota Tanah pada Agroekosistem Tanpa Olah Tanah. Makalah Falsafah Sains. IPB.

PT. GMP. 2010. Data Sekunder PT. Gunung Madu Plantation Diakses Melalui http:// www.detikfinance.com/read/2006/05/03/174035/ 587594/4/ impor gula palsu meningkat konsumen diminta waspada pada tanggal 26 April 2015.

Robinson T. 1995. Kandungan Organik Tumbuhan Tinggi. Padmawinata K, penerjemah. Bandung: 
Institut Teknologi Bandung. Terjemahan dari: The Organic Constitutes of Higher Plants.

Rovira, A. D. and E. L Greacen, 1957.The Effect of Agregate Disruption on the Activity of Microorganism in the Soil. Agust J. Agr. Res 8659.

Sarno, S. Yusnaini, Dermiyati dan M.Utomo.1998. Pengaruh Sistem Olah Tanah dan Pemupukan Nitrogen Jangka Panjang Terhadap Kandungan Asam Humik dan Fulfik. J. Tanah Trop. 7:3542.

Sarno, M. Iijima, J. Lumbanraja, Sunyoto, E.Yuliadi, Y. Izumi, and A.Watanabe. 2004. Soil chemical properties of an Indonesian red acid soilas affected by land use and crop management. Soil and Tillage Research. 76 : 115-124.

Singaram t., Devi R.D. 2005.Effect of lignite humic acid and fertilizers on the yield of onion and nutrient availability. Proceedings of 18th World Congress of Soil Science July 9-15. Philadelphia, Pennsylvania, USA.

Sitepu, R. 2006. Perbedaan antara Bagasse Lama dan Bagasse Baru jika Digunakan sebagai Bahan Baku Kompos. Progresta edisi Oktober 2006.
Soepardi, G. 1993. Sifat dan Ciri Tanah. FapertaIPB. Bogor. $591 \mathrm{hlm}$.

Stevenson, F.T. (1982) Humus Chemistry. John Wiley and Sons, Newyork.

Tan. K. H. 1995. Dasar-Dasar Kimia Tanah. Gadjah Mada University Press. Yogyakarta.

Tate, R. L. 1987. Soil Organic Matter: Biological And Ecological Effects. John Wiley and Sons, Inc.

Utomo, M. 2006. Bahan baku pengelolaan lahan kering berkelanjuan.Universitas Lampung Bandar Lampung. $25 \mathrm{hlm}$.

Utomo, M. 1990. Budidaya Pertanian Tanpa Olah Tanah, Teknologi untuk PertanianBerkelanjutan. Direktorat Produksi Padi dan Palawija, Departemen Pertanian. Jakarta.

Widodo Eko A.2015. Pengaruh Pengolahan Tanah dan Pemberian Mulsa Bagas Terhadap Biomassa Karbon Mikroorganisme Tanah ( C-mik) Pada Lahan Pertanaman Tebu PT GMP tahun Ketiga. Skripsi. Universitas Lampung 